\title{
Causes of low vision and blindness in a Turkish adult population: the Izmir eye study
}

Feray Koç, ${ }^{1}$ Veysi Erden ${ }^{1}$ and Nazife Sefi-Yurdakul ${ }^{2}$

${ }^{1}$ Izmir Ataturk Education and Research Hospital, Izmir, Turkey (Correspondence to: Feray Koc: dr_feray@yahoo.com..Baskent University, Izmir, Turkey.

\begin{abstract}
Background: Data from Turkey show that sense organ diseases were the second leading cause of years lost due to disability in 2015. However, there are no reliable data on either the baseline causative disorders of visual impairment or the burden of these disorders on the population in Izmir region. Izmir is the third most populated city of Turkey with a population of approximately 4.2 million.

Aim: The purpose of this study was to define the baseline disorders causing low vision and blindness in accordance with World Health Organization criteria in an adult population in Izmir.

Methods: We evaluated the ophthalmologic reports of 20790 people in Izmir, Turkey. Age- and sex-specific causes of low vision and blindness were identified.

Results: Bilateral low vision and blindness was detected in 347 people, 172 males and 175 females. For those aged 18-50 years, retinal dystrophies (37\%), congenital eye anomalies (14\%) and myopic degenerations (13\%) were the most common causes. For those aged 50+ years, age-related macular degeneration (21\%) was the leading cause. Diabetic retinopathy (17\%), corneal opacities (14\%), cataract (12\%) and glaucoma (9\%) were also important. Sex was not a significant determinant.

Conclusion: The specific causes of visual impairment vary greatly with age, however, unavoidable retinal pathologies were the predominant causes at all ages.

Keywords: Blindness, low vision, adults, Izmir

Citation: Koc F; Erden VE; Sefi-Yurdakul N. Causes of low vision and blindness in a Turkish adult population: the Izmir eye study. East Mediterr Health J. 2018;24(2):161-168. https://doi.org/10.26719/2018.24.2.161.

Received: 12/04/16; accepted: 08/03/17

Copyright (c) World Health Organization (WHO) 2018. Some rights reserved. This work is available under the CC BY-NC-SA 3.0 IGO license (https:// creativecommons.org/licenses/by-nc-sa/3.o/igo).
\end{abstract}

\section{Introduction}

Low vision and blindness are important public health problems. Persons with visual impairment usually need support and assistance unless they get vision rehabilitation with the provision of low vision devices, orientation and mobility training and counselling for making specific modifications in their living environment for proper adaptation towards performing day to day activities and social integration. This process requires extra costs for both families and the community. Data from the Institute for Health Metrics and Evaluation data about Turkey showed that sense organ diseases were the second leading cause of years lost due to disability in 2015 (1). However, there have been no reliable data showing either the baseline causative disorders of visual impairment or the burden of these disorders on the population in Izmir region.

Izmir is the third most populated city of Turkey with a population of approximately 4.2 million. It is located in the south-west of the country. Life expectancy is 74.6 years for males and 80.5 for females. Around $27 \%$ of the population is over the age of $50(2,3)$.

The purpose of this study was to define the baseline disorders causing low vision and blindness in adult population of Izmir in accordance with World Health Organization (WHO) criteria (4).

\section{Methods}

The medical records of 20790 people aged $\geq 18$ years who were admitted to Atatürk Education and Research Hospital health council to get a health certificate between January 2012 and December 2013 were reviewed retrospectively after the study protocol was approved by the ethics committee.

Common reasons for attending the health council were to get a health report to be a candidate for certain academies and professions, to move nursing homes, to get a driving licence, to receive disability benefits (e.g. tax discount, nursing services at home, financial support assistance) and to be included in the employment quota for disabled people.

All attendees had basic ocular examinations, including visual acuity testing, slit lamp examination with a dilated posterior segment examination and intraocular pressure measurement. If the visual acuity level was less than $20 / 20$, it was retested with the autorefraction result in a trial frame to obtain the best-corrected visual acuity. If a psychogenic visual acuity loss was suspected, it was 
retested using several tests for evaluation of psychogenic visual loss. If the level of obtained visual acuity was not correlated with the ocular findings of the subject, a pattern visual evoked potential test was ordered. Subjects were referred for visual field screening using the Humphrey Perimeter Central 30-2 Swedish Interactive Threshold Algorithm when there was pathology affecting the visual field. Ocular ultrasonography was ordered when the optical medium was not clear enough to visualize the retina, and optical coherence tomography was ordered if macular or optic disc pathology was suspected.

\section{Definitions of low vision and blindness}

The WHO categories of visual impairment were used for this study (4). Visual acuity levels were converted into the logarithmic scale equivalents using available conversion charts to classify patients according to the WHO criteria. Low vision was defined as best-corrected visual acuity in the better eye $<20 / 70$ but $\geq 20 / 400$, and blindness was defined as best-corrected visual acuity in the better eye $<20 / 400$ or visual field constricted within $10^{\circ}$ of fixation bilaterally (4).

\section{Causes of low vision or blindness}

The principal cause of visual impairment in the eye in question was determined by a senior ophthalmologist based on clinical records obtained from all examinations and available past history and records of the patient. In eyes with 2 or more disorders that might have caused the visual impairment, the disorder with the presumed greatest clinical impact on the visual acuity was considered the principal cause. If the principal cause of visual impairment was different in each eye, the pathology of the better eye was considered the principle pathology for that patient because low vision and blindness were defined in terms of the better-seeing eye.

\section{Statistical analysis}

Descriptive analyses of the data were made using SPSS, version 15 . All data were reported as mean and standard deviation. Continuous variables in the groups were compared using the independent-samples t-test and the categorical variables were compared using the chi-squared test. The level of significance was determined as $P<0.05$.

\section{Results}

The total number of patients included in the study was 347 (172 men, 175 women), who were classified in the low vision and blindness category according to WHO criteria (4). Seven patients who could not give reliable responses to the visual acuity testing because of mental problems were excluded.

For better presentation of the pathologies causing visual impairment, we categorized all the diseases under 13 main categories (Table 1).

The distribution of the pathologies causing low vision and blindness according to age and sex is shown in Table 2. Distribution of the common pathologies was statistically different between age subgroups 18-50 and $50+$ years $(P<0.001)$, but not between sex subgroups $(P>0.05)$ The most common pathologies causing visual impairment were retinal dystrophies, myopic degeneration and congenital eye anomalies for the 1850 years age group and these were age-related macular degenerations, diabetic retinopathy and corneal opacities for the $50+$ years age group.

Distribution of the pathologies leading to low vision and blindness categories according to age is given in Table 3. Ten people were classified as either having low vision or blind using the visual field criterion and the rest using visual acuity. Retinal dystrophies (7 patients) and glaucoma (3 patients) were the causes of severe visual field constrictions. The severity of visual impairment tended to increase with age: blindness was the predominant category in the 50+ years age group while low vision was predominant in the 18-50 years age group $(P=0.063)$. Pathologies for low vision and blindness in

\begin{tabular}{|c|c|}
\hline Disease category & Pathologies \\
\hline Diabetic retinopathy & Diabetic macular oedema, Proliferative diabetic retinopathy, including retinal detachment \\
\hline Optic atrophy & $\begin{array}{l}\text { Ischemic, compressive, toxic, traumatic, autoimmunogenic, excluding optic atrophies secondary to } \\
\text { glaucoma and uveitic syndromes }\end{array}$ \\
\hline Cataract & All types of cataract \\
\hline Retinal vascular disease & Central retinal vein occlusion and central retinal artery occlusions not associated with uveitic syndromes \\
\hline Corneal opacities & Corneal degenerations, traumatic, postinfectious, iatrogenic \\
\hline Congenital eye anomalies & Microphthalmus, albinism, anopthalmus, Peters anomaly, optic disc and chorioretinal coloboma \\
\hline Myopic degenerations & Myopic macular degeneration, retinal detachment \\
\hline Glaucoma & All primary and secondary glaucomas, congenital glaucoma \\
\hline Retinal dystrophy & Retinitis pigmentosa, Usher syndrome, Stargardt disease, Bietti crystalline dystrophy, choroideraemia \\
\hline Age-related macular degeneration & Senile macular degenerations and all macular scars of unknown etiology \\
\hline Phthisis bulbi/absent globe & Traumatic, postsurgical \\
\hline Uveitis & Behçet syndrome, sarcoidosis \\
\hline Amblyopia & Deprivation amblyopia due to delayed congenital cataract surgery, aphakia \\
\hline
\end{tabular}




\begin{tabular}{|c|c|c|c|c|c|c|c|c|c|c|}
\hline \multirow[t]{4}{*}{ Pathology } & \multicolumn{8}{|c|}{ Age (years) } & \multicolumn{2}{|c|}{ Total } \\
\hline & \multicolumn{4}{|c|}{$18-50$} & \multicolumn{4}{|c|}{$50+$} & \multirow[b]{3}{*}{ No. } & \multirow[b]{3}{*}{$\%$} \\
\hline & \multicolumn{2}{|c|}{ Females } & \multicolumn{2}{|c|}{ Males } & \multicolumn{2}{|c|}{ Females } & \multicolumn{2}{|c|}{ Males } & & \\
\hline & No. & $\%$ & No. & $\%$ & No. & $\%$ & No. & $\%$ & & \\
\hline Diabetic retinopathy & 0 & 0.0 & 4 & 7.7 & 18 & 14.4 & 24 & 20.0 & 46 & 13.3 \\
\hline Optic atrophy & 6 & 12.0 & 4 & 7.7 & 8 & 6.4 & 8 & 6.7 & 26 & 7.5 \\
\hline Cataract & 0 & 0.0 & 0 & 0.0 & 17 & 13.6 & 12 & 10.0 & 29 & 8.4 \\
\hline Retinal vascular disease & 0 & 0.0 & 0 & 0.0 & 0 & 0.0 & 2 & 1.7 & 2 & 0.6 \\
\hline Corneal opacities & 3 & 6.0 & 4 & 7.7 & 17 & 13.6 & 17 & 14.2 & 41 & 11.8 \\
\hline Congenital eye anomalies & 4 & 8.0 & 10 & 19.2 & 3 & 2.4 & 40 & 3.3 & 21 & 6.1 \\
\hline Myopic degenerations & 7 & 14.0 & 6 & 11.5 & 12 & 9.6 & 5 & 4.1 & 30 & 8.7 \\
\hline Glaucoma & 2 & 4.0 & 1 & 1.9 & 10 & 8.0 & 11 & 9.2 & 24 & 6.9 \\
\hline Retinal dystrophies & 20 & 40.0 & 18 & 34.6 & 12 & 9.6 & 9 & 7.5 & 59 & 17.0 \\
\hline Age-related macular degeneration & 0 & 0.0 & 1 & 1.9 & 27 & 21.6 & 25 & 20.8 & 53 & 15.3 \\
\hline Phthisis bulbi/absent globe & 1 & 2.0 & 0 & 0.0 & 0 & 0.0 & 1 & 0.8 & 2 & 0.6 \\
\hline Uveitis & 3 & 6.0 & 1 & 1.9 & 0 & 0.0 & 1 & 0.8 & 5 & 1.4 \\
\hline Amblyopia & 4 & 8.0 & 3 & 5.8 & 1 & 0.8 & 1 & 0.8 & 9 & 2.6 \\
\hline Total & 50 & 100.0 & 52 & 100.0 & 125 & 100.0 & 120 & 100.0 & 347 & 100.0 \\
\hline \multirow[t]{2}{*}{$P$-value } & \multicolumn{4}{|c|}{0.378} & \multicolumn{4}{|c|}{0.686} & & \\
\hline & & & & & & & & & & \\
\hline
\end{tabular}

the $18-50$ years age group were similar $(P=0.378)$, but in the $50+$ years group, the top 3 pathologies for low vision and blindness tended to differ $(P=0.058)$.

\section{Discussion}

Meta-analysis of population-based studies showed that the causes of blindness differ substantially by region (5), with the prevalence of cataract being lowest and that of macular degeneration being greatest in the highest-income regions. Worldwide, more women than men were blind or had low vision (5). Turkey can be classified among the low- to middle-income countries, but includes regions with varying socioeconomic, geographic, and ethnic characteristics (6).

The Turkish Statistical Instituteran astudy throughout the country based on questionnaire assessments rather than clinical examinations in 2002 and found the prevalence of visual impairment in Izmir region to be $0.69 \%$ (7). However, this study did not give any information about the main pathologies causing visual impairment. The current study provides reliable information about the causes of low vision and blindness in the adult population of Izmir: the major causes of blindness and low vision were, in order, retinal dystrophies, congenital eye anomalies and myopic degeneration for the 18-50 years age group. Age-related macular degenerations, diabetic retinopathy and corneal opacities were the most common causes of visual impairment for the 50+ years age group. Cataract and glaucoma were not among the 3 leading causes of total visual impairment, but cataract was the third most common in the low vision category, and glaucoma was the third most common in blindness category in 50+ years group. Major causes of vision loss were unavoidable diseases, and no gender predilection was observed.

Recently, Kivanc et al. reported a similar study from Erzurum region in Turkey (8). Although their study population was also selected from health council medical records, they studied subjects aged 64 years or over and used a different disease categorization method, which precludes direct comparison with our results. However, cataract was the leading cause of low vision, and the second most common cause of blindness after glaucoma in their group. Besides, women constituted the majority (64\%) of their blind group. Both cataract, and glaucoma are avoidable causes of visual impairment. The differences between the 2 regions of Turkey might result from the possible differences in access to and use of eye care services between the regions. Erzurum is located in the eastern part of Turkey, and both geographic and socioeconomic characteristics are rather different from Izmir.

One of the main findings of our study was that retinal dystrophies were the most common reason for low vision and blindness in the 18-50-year-old population. Retinal dystrophies were not found as a major cause of visual impairment in the study from Erzurum because that study was not done on an age-matching group (8). Retinal dystrophies have also been reported as one of the main causes of blindness in Scandinavian (28.6\%), German (22\%), English, (8.2\%) and Chinese populations (7.7\%) (9-12). To provide a better comparison, studies detailing 


\begin{tabular}{|c|c|c|c|c|c|c|c|c|c|c|}
\hline \multirow[t]{4}{*}{ Pathology } & \multicolumn{8}{|c|}{ Age (years) } & \multicolumn{2}{|c|}{ Total } \\
\hline & \multicolumn{4}{|c|}{$18-50$} & \multicolumn{4}{|c|}{$50+$} & \multirow[b]{3}{*}{ No. } & \multirow[b]{3}{*}{$\%$} \\
\hline & \multicolumn{2}{|c|}{ Low vision } & \multicolumn{2}{|c|}{ Blindness } & \multicolumn{2}{|c|}{ Low vision } & \multicolumn{2}{|c|}{ Blindness } & & \\
\hline & No. & $\%$ & No. & $\%$ & No. & $\%$ & No. & $\%$ & & \\
\hline Diabetic retinopathy & 3 & 5.2 & 1 & 2.3 & 25 & 22.3 & 17 & 12.8 & 46 & 13.3 \\
\hline Optic atrophy & 5 & 8.6 & 5 & 11.4 & 7 & 6.3 & 9 & 6.8 & 26 & 7.5 \\
\hline Cataract & 0 & 0.0 & 0 & 0.0 & 16 & 14.3 & 13 & 9.8 & 29 & 8.4 \\
\hline Retinal vascular disease & 0 & 0.0 & 0 & 0.0 & 1 & 0.9 & 1 & 0.8 & 2 & 0.6 \\
\hline Corneal opacities & 4 & 6.9 & 3 & 6.8 & 15 & 13.4 & 19 & 14.3 & 41 & 11.8 \\
\hline Congenital eye anomalies & 7 & 12.1 & 7 & 15.9 & 3 & 2.7 & 4 & 3.0 & 21 & 6.1 \\
\hline Myopic degenerations & 8 & 13.8 & 5 & 11.4 & 7 & 6.3 & 10 & 7.5 & 30 & 8.7 \\
\hline Glaucoma & 1 & 1.7 & 2 & 4.5 & 3 & 2.7 & 18 & 13.5 & 24 & 6.9 \\
\hline Retinal dystrophy & 21 & 36.2 & 17 & 38.6 & 6 & 5.4 & 15 & 11.3 & 59 & 17.0 \\
\hline Age-related macular degeneration & 1 & 1.7 & 0 & 0.0 & 27 & 24.1 & 25 & 18.8 & 53 & 15.3 \\
\hline Phthisis bulbi/absent globe & 0 & 0.0 & 1 & 2.3 & 0 & 0.0 & 1 & 0.8 & 2 & 0.6 \\
\hline Uveitis & 2 & 3.4 & 2 & 4.5 & 0 & 0.0 & 1 & 0.8 & 5 & 1.4 \\
\hline Amblyopia & 6 & 10.3 & 1 & 2.3 & 2 & 1.8 & 0 & 0.0 & 9 & 2.6 \\
\hline Total & 58 & 100.0 & 44 & 100.0 & 112 & 100.0 & 133 & 100.0 & 347 & 100.0 \\
\hline$P$-value & & & & & & & & & & \\
\hline
\end{tabular}

major causes of visual impairment from countries with different income levels have been listed on Table 4. Retinal dystrophies were usually not reported as a major cause of visual loss in middle- to lower-income countries $(8,13-16)$. It is possible that a higher proportions of uncorrected refractive error and cataract might be masking retinal dystrophies in those regions of the world.

Congenital eye anomalies were the second most common (15.9\%) pathology causing blindness in the $18-50$ years age group, and predominantly affected males (19.2\% vs $8 \%$ ). It is difficult to compare our findings with other studies, because either a congenital eye malformations were not categorized or they were categorized under "others" in many of the studies $(9,10,14-16)$. Finger et al. categorized congenital malformations and retinopathy of prematurity together in the "others" category (10), and this category accounted for blindness in $37.2 \%$ of a German population (Table 4). Congenital eye anomalies were reported as the cause of blindness in $4 \%$ of the blind registered Australian and 2.1\% of the blind registered English populations (11,17). Strikingly higher proportions of visual impairment associated with congenital eye anomalies in our study population might have arisen from limited access to eye care services in the past and lack of timely treatment in some cases.

We found that myopic degenerations were the second most common cause of low vision, (13.8\%) and the third most common cause of blindness (11.4\%) in the $18-50$ years age group; females were more commonly affected. Similar proportions for myopic degenerations have been reported in Scandinavian (14\%), Australian (9.5\%), Chinese (7.7 \%), and German (7.5\%) populations $(9,10,12,17)$. For the myopia-related low vision category reported proportions were: $32.7 \%$ for Chinese, $26 \%$ for Scandinavian and $12.2 \%$ for Japanese populations $(9,12,18)$. On the other hand, myopic degeneration was not categorized in studies from both lower- (India, Pakistan, Iran, Brazil, Oman), and higherincome (United States of America, England and Wales) regions of the world (11,13-16,19,20). Myopic degenerations might be categorized under headings like "others", "other retinal diseases", "maculopathy", "uncorrected refractive errors" and "macular degeneration" in different studies, and this might lead to a false impression that they are very rare in some populations. Another possibility is that higher proportions of cataract might be masking posterior segment problems like myopic degenerations.

Age-related macular degeneration is reported as the most common cause of low vision and blindness in many high-income countries except for Japan $(11,17,18,20)$. It was also the leading cause of low vision $(24.1 \%)$ and blindness $(18.8 \%)$ in both males and females in the $50+$ years age group in Izmir, but the proportion of the population blind because of age-related macular degeneration was not particularly high compared with the proportions from higher-income countries, where age-related macular degeneration was the major cause of blindness in $27-65 \%$ of the cases $(9,10,17,20)$. On the other hand, age-related macular degeneration was not reported among the major causes of low vision and blindness, or had a minor role, in most of the low- and middle-income countries (12-16).

Diabetes mellitus is one of the most common chronic diseases in nearly all countries, and the prevalence is expected to increase as changing lifestyles lead to reduced physical activity and increased obesity (21). 


\begin{tabular}{|c|c|c|c|c|}
\hline Region and date & No. & Age (years) & Criteria for LV\&B & Leading causes of LV\&B \\
\hline \multirow[t]{2}{*}{ Izmir/Turkey 2016 (this study) } & 44 & $18-50$ & WHO (LV\&B) & Retinal dystrophies, malformations, MRD \\
\hline & 133 & $50+$ & WHO (LV\&B) & AMD, DRP, corneal opacities \\
\hline Erzurum, Turkey 2016 (8) & 71 & $65^{+}$ & WHO (LV\&B) & Cataract, glaucoma, AMD \\
\hline Beijing, China 2006 (12) & 62 & $40+$ & WHO (LV\&B) & Cataract, MRD, glaucoma \\
\hline Iran $2015(15)$ & 156 & All ages & WHO (LV\&B) & Uncorrected refractive error, cataract, AMD \\
\hline Brazil 2009 (16) & 42 & All ages & WHO (LV\&B) & $\begin{array}{l}\text { Uncorrected refractive error, Cataract, retinal } \\
\text { diseases }\end{array}$ \\
\hline Pakistan 2014 (13) & 2927 & $30+$ & WHO (LV\&B) & $\begin{array}{l}\text { Cataract, uncorrected refractive error and } \\
\text { aphakia }\end{array}$ \\
\hline India 2014 (14) & 1609 & $50+$ & WHO (LV\&B) & $\begin{array}{l}\text { Uncorrected refractive error, cataract, retinal } \\
\text { disease }\end{array}$ \\
\hline USA (white) 2004 (20) & $937000^{\mathrm{a}}$ & $40+$ & USA (B) & AMD, cataract, glaucoma \\
\hline USA (Hispanic) 2004 (20) & $937000^{\mathrm{a}}$ & $40+$ & USA (B) & Glaucoma, AMD, DRP \\
\hline USA (black) 2004 (20) & $937000^{a}$ & $40+$ & USA (B) & Cataract, glaucoma, DRP \\
\hline \multirow[t]{2}{*}{ Germany 2015 (10) } & 949 & $20-60$ & WHO (B) & $\begin{array}{l}\text { Malformations and ROP, retinal dystrophy, } \\
\text { glaucoma }\end{array}$ \\
\hline & 1465 & $61-80$ & WHO (B) & AMD, DRP, malformations and ROP \\
\hline \multirow[t]{2}{*}{ Copenhagen, Denmark 2004 (9) } & 209 & $20-64$ & USA (LV\&B) & MRD, other retinal diseases, DRP \\
\hline & 320 & $65-84$ & USA (LV\&B) & Cataract, AMD, DRP \\
\hline Australia $2011(17)$ & 273 & All ages & USA (B) & AMD, glaucoma, retinal dystrophies \\
\hline England and Wales 2013 (11) & 10781 & All ages & WHO (B) & AMD, glaucoma, retinal dystrophies \\
\hline Poland 2015 (23) & 20 & $35^{+}$ & USA (LV\&B) & AMD, cataract, glaucoma \\
\hline Japan 2006(18) & 25 & $40+$ & USA (LV\&B) & Cataract, MRD, glaucoma \\
\hline Oman 2014 (19) & 134 & All ages & WHO (B) & $\begin{array}{l}\text { Cataract, trachomatous corneal opacities, } \\
\text { glaucoma }\end{array}$ \\
\hline
\end{tabular}

WHO = World Health Organization; $L V \& B=$ low vision and blindness; $M R D=$ myopic retinal disease; $A M D=$ age related macular degenerations; $D R P=$ diabetic retinopathy; $U S A=$ United States of America; $R O P$ = retinopathy of prematurity.

${ }^{a}$ Estimated number.

Recent studies have reported that the prevalence of diabetes mellitus in Turkey is increasing rapidly: a 90\% increase from 1999 to 2010 has been reported (22). Diabetic retinopathy was the second leading cause of low vision and the fourth leading cause of blindness in the 50+ years age group in our study, predominantly affecting the male population. Blindness due to diabetic retinopathy was comparable in German (20\%), Scandinavian (14\%), Hispanic American (14.3\%), Black American (7.3\%) and Chinese $(7.7 \%)$ populations $(9,10,12,20)$. However, it did not seem to be such a major problem in countries like Japan, Australia, Islamic Republic of Iran, Pakistan, Poland or Brazil although they had comparable prevalence rates of diabetes mellitus $(13,15-18,21,23)$. This might be attributed to better control of diabetes mellitus, timely treatment of diabetic eye complications, or under-representation of diabetic retinopathy as a cause of visual impairment because of higher prevalence of cataract. Besides, cataract itself might be a complication of diabetes mellitus.

Cataract was reported the cause of $33.4 \%$ of all blindness in 2010 , and $18.4 \%$ of all low vision worldwide (24). It was a major cause of blindness in low-income countries like India (62.4\%), Pakistan (51.5\%) and China (38.5\%), but in high-income countries it was often reported as a major cause of low vision (9,11-14,17). Cataract surgery can be readily performed in hospitals in Izmir, and it was not a major cause of blindness, however, it was the third most common cause of low vision in the 50+ years age group (14.3\%).

Glaucoma had a unique distribution in visually impaired patients. Glaucoma patients usually preserve a good level of visual acuity until the end stage of the disease. Consistent with this, glaucoma was not found to be a common cause of low vision in our study, although it was the third most common cause of blinding pathology after age-related macular degeneration and diabetic retinopathy in the $50+$ years age group. A similar distribution of glaucoma-related visual impairment was observed in Scandinavian, Hispanic American and Black American populations $(9,20)$. Glaucoma was the leading cause of blindness in Hispanic Americans, with a typical distribution of $28.6 \%$ in the blind group, and a much lower $7.6 \%$ in the low vision group (20). It was reported as a common cause of blindness in both high- and lowincome countries, e.g. Germany (15\%), China (7.7\%) and Pakistan (7.1\%) $(10,12,13)$. Visual impairment, caused by glaucoma, can be prevented by early detection and close follow-up of the affected individuals. Primary open-angle 
glaucoma, which is the most common type observed in our population, usually does not cause signs or symptoms, and is diagnosed during ophthalmologic examination for other reasons. Early diagnosis of all cases is only possible by regular screening programmes aimed towards age groups of the population with a relatively higher risk.

Corneal opacities arising from various causes were the third most common cause of visual impairment in both men and women aged 50+ years. They were also the third most common cause of blindness in the $50+$ years age group. Corneal opacities were not reported among the common causes of low vision and blindness in highincome countries (9-11), but they were the second most common cause of blindness in studies from Pakistan $(11.8 \%)$ and China (15.4\%) (12,13). Higher proportions of blindness due to corneal opacities were especially reported in countries where trachoma was seen endemically $(19,25)$. Trachoma was not seen in Turkey. Causes of corneal opacities in the study population were corneal degeneration, trauma, post infection (nontrachomatous), iatrogenic and idiopathic.

A limitation of this study was that it had to rely on data collected by the health council, and maintained in their archives, with no opportunity to verify the diagnosis. However, all reports submitted were based on examinations completed by a senior ophthalmologist; therefore, the level of accuracy is assumed to be high.

\section{Conclusions}

There was no sex difference in the distribution of the pathologies causing low vision and blindness, but there were significant differences due to age. Among adults aged 18-50 years, especially retinal dystrophies and congenital eye anomalies had striking high percentages compared to other countries. Identifying the inheritance pattern and the causative genetic mutations in the affected patients might facilitate genetic counselling, and consequently reduce the disease incidence in the next generations (26).

Age-related macular degenerations, diabetic retinopathy and corneal opacities were the predominant pathologies causing low vision and blindness in persons aged 50+ years. Age-related macular degeneration is not preventable; as the life expectancy of the population increases, the prevalence of age-related macular degeneration is also expected to increase, and health service planners should consider the medical and social service requirements for this cohort of the population. On the other hand, diabetic retinopathy is preventable: awareness of glycaemic control is necessary to prevent vision-threatening complications of diabetes.

Corneal opacities have strikingly higher proportions among the visually impaired population although it is a treatable pathology. In 2013, the Turkish government allowed the importation of corneas and the law on organ and tissue transplantation was changed in 2014, allowing corneas to be taken from dead donors unless they left a signed will prohibiting it. Thus, we can expect that corneal opacities might not be a major cause of visual impairment in the region in the near future, and our findings may provide a firm basis for the future planning and strengthening of comprehensive eye care services in Izmir.

Funding: None.

Competing interests: None declared.

\section{Causes de la faible vision et de la cécité dans une population adulte turque : étude de santé oculaire à Izmir \\ Résumé}

Contexte : En Turquie, les données montrent que les maladies des organes des sens représentaient la deuxième cause d'années de vie perdues en raison d'une incapacité en 2015. Cependant, il n'existe de données fiables ni sur les troubles de base à l'origine de la déficience visuelle, ni sur la charge de ces troubles dans la population de la région d'Izmir. Izmir constitue la troisième ville la plus peuplée de Turquie, avec une population d'environ 4,2 millions d'habitants.

Objectif : La présente étude avait pour objectif de définir les troubles de base à l'origine d'une faible vision et de la cécité dans une population adulte d'Izmir, selon les critères de l'Organisation mondiale de la Santé.

Méthodes : Nous avons évalué les rapports ophtalmologiques de 20790 personnes à Izmir (Turquie). Les causes de la faible vision et de la cécité liées à l'âge et au sexe ont été identifiées.

Résultats: Une faible vision et une cécité bilatérales ont été détectées chez 347 personnes, dont 172 hommes et 175 femmes. Pour les sujets âgés de 18 à 50 ans, les dystrophies rétiniennes (37\%), les anomalies oculaires congénitales (14\%) et la dégénérescence myopique $(13 \%)$ constituaient les causes les plus courantes. Pour ceux âgés de plus de 50 ans, la dégénérescence maculaire (21\%) liée à l'âge était la cause principale. La rétinopathie diabétique (17\%), les opacités cornéennes (14\%), la cataracte $(12 \%)$ et le glaucome $(9 \%)$ étaient aussi des causes importantes. Le sexe ne constituait pas un déterminant significatif.

Conclusion : Les causes spécifiques de la déficience visuelle varient grandement en fonction de l'âge ; néanmoins, les pathologies rétiniennes non évitables étaient les causes prédominantes à tout âge. 


$$
\begin{aligned}
& \text { أسباب ضعف الإبصار والعمى في إحدى بجموعات السكان البالغين في تركيا: دراسة حول أمر اض العيون في إزمير } \\
& \text { فراي كوج، ويسي أمره اردن، نازيفه صفي يورداكول } \\
& \text { الخلاصة }
\end{aligned}
$$

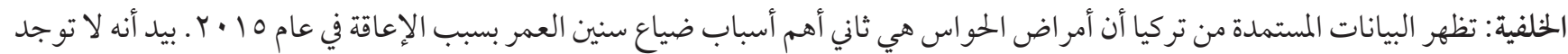

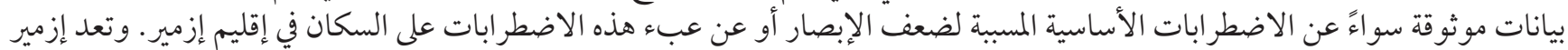

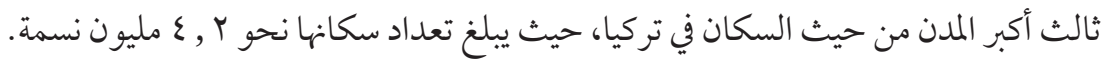

$$
\begin{aligned}
& \text { الهدف: تمثل الغرض من هذه الدراسة في تحديد الاضطر ابات الأساسية المسبِّة لضعف الإبصار والعمى وفق معايير منظمة الصحة العالمية لدى }
\end{aligned}
$$

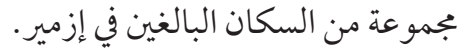

$$
\begin{aligned}
& \text { طرق البحث: أجرينا تقيياً لتقارير العيون لما جموعه • Vq · · شخصاً في إزمير بتركيا. وتم تحديد أسباب ضعف الإبصار والعمي حسب العمر } \\
& \text { والجنس. }
\end{aligned}
$$

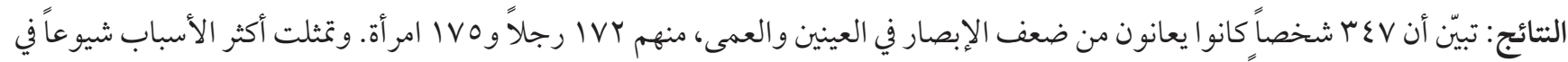

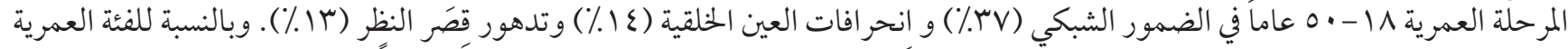

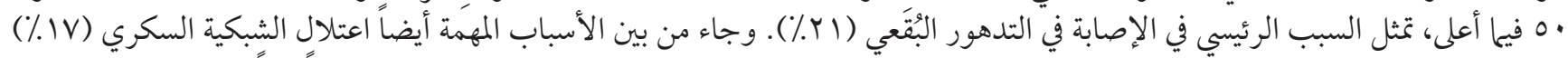

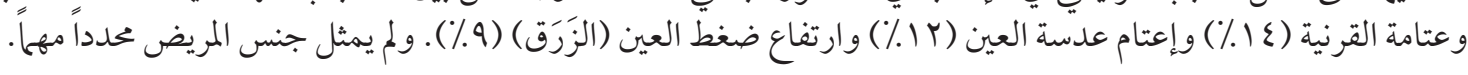

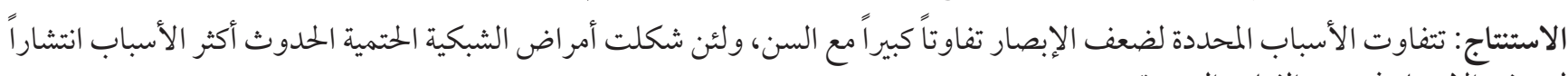

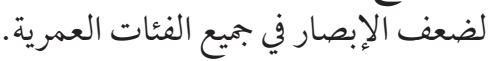

\section{References}

1. GDB 2015 SDG Collaborators. Measuring the health related Sustainable Development Goals in 188 countries, a baseline analysis from the Global Burden of Disease Study 2015. Lancet. 2016 Oct;10053)388):50-1813. PMID:27289173

2. [Life tables 2014-2013]. Ankara: Turkish Statistical Institute; 2014 (http://www.tuik.gov.tr/UstMenu.do?metod=temelist, accessed 7 November 2017) (in Turkish).

3. [Izmir population]. Izmir: Turkish Statistical Institute; 2016 (in Turkish) (http://www.nufusu.com/il/izmir-nufusu, accessed 19 October 2017).

4. International statistical classification of diseases and related health problems, 1oth rev; Ch VII Diseases of the eye and adnexa (Hoo-H59). Geneva: World Health Organization; 2016 (http://apps.who.int/classifications/icd1o/browse/2016/en\#/VII, accessed 6 November 2017).

5. Bourne RR, Steven GA, White RA, Smith JL, Flaxman SR, Price H et al. Causes of vision loss worldwide, 2010-1990: a systematic analysis. Lancet Glob Health. 2013 Dec;6)1):e49-339. PMID:25104599

6. CIA world factbook: country comparison: GDP - per capita (PPP). Washington DC: Central Intelligence Agency; 2016 (https:// www.cia.gov/library/publications/the-world-factbook/rankorder/2004rank.html, accessed 12 December 2017).

7. Turkey disability survey 2002. Ankara: State Institute of Statistics \& Presidency of the Administration for Disabled People; 2002 (http://kutuphane.tuik.gov.tr/pdf/0014899.pdf, accessed 19 October 2017).

8. Kivanc SA, Akova-Budak B, Olcaysu OO, Cevik SG. Sociodemographic status of severely disabled and visually impaired elderly people in Turkey. Arq Bras Oftalmol. 2016 Feb;1)79):9-24. PMID:26840162

9. Buch H. Prevalence and causes of visual impairment and blindness among 9980 Scandinavian adults: The Copenhagen City Eye Study. Ophthalmology. 1)111;2004):61-53. PMID:14711714

10. Finger RP, Fimmers R, Holz FG, Scholl HP. Prevalence and causes of registered blindness in the largest federal state of Germany. Br J Ophthalmol. 8)95;2011):7-1061. PMID:21378005

11. Quatilho A, Simkiss P, Zekite A, Xing W, Wormald R, Bunce C. Leading causes of certifiable visual loss in England and Wales during the year ending 31 March 2013. Eye (Lond). 4)30;2016):7-602. PMID:26821759

12. Xu L, Wang Y, Li Y, Wang Y, Cui T, Li J, et al. Causes of blindness and visual impairment in an urban and rural area in Beijing: the Beijing Eye Study. Ophthalmology. 7)113;2006):1141.e11-1. PMID:16647133

13. Dineen B, Bourne PRA, Jadoon Z, Shah SP, Khan MA, Foster A, et al. Causes of blindness and visual impairment in Pakistan. The Pakistan national blindness and visual impairment survey. Br J Ophthalmol. 10-91:1005;2007. PMID:17229806

14. Murthy GV, Gupta SK, Bachani D, Jose R, John N. Current estimates of blindness in India. Br J Ophthalmol. 3)89;2005):60-257. PMID:15722298

15. Hashemi H, Rezvan F, Yekta A, Ostadimoghaddam H, Soroush S, Dadbin N et al. The prevalence and causes of visual impairment and blindness in rural population in the north of Iran. Iran J Public Health. 2015 Jun;6)44):64-855. PMID:26258099 
16. Schellini SA, Durkin SR, Hoyama E, Hirai F, Cordeiro R, Casson RJ et al. Prevalence and causes of visual impairment in a Brazilian population: the Botucatu Eye Study. BMC Ophthalmol. 2009 Aug;9:8. PMID:19691835

17. Crewe JM, Morgan WH, Morlet N, Spilsbury K, Mukhtar A, Clark A, et al. Assessing the diagnostic validity of a blind register. Clin Exp Ophthalmol. 6)39;2011):500-494. PMID:21819503

18. Iwase A, Araie M, Tomidokoro A, Yamamoto T, Shimizu H, Kitazawa Y. Tajimi Study Group. Prevalence and causes of low vision and blindness in a Japanese adult population: the Tajimi Study. Ophthalmology. 8)113;2006):62-1354. PMID:16877074

19. Khandekar R, Mohammed AJ, Negrel AD, Al Riyami A. The prevalence and causes of blindness in the Sultanate of Oman: the Oman Eye Study. Br J Ophthalmol. 62-86:957;2002. PMID:12185115

20. Congdon N, O'Colmain B, Klaver CC, Klein R, Munoz B, Friedman DS et al. Causes and prevalence of visual impairment among adults in the United States. Arch Ophthalmol. 2004 Apr;4)122):85-477. PMID:15078664

21. Shaw JE, Sicree RA, Zimmet PZ. Global estimates of the prevalence of diabetes for 2010 and 2030. Diabetes Res Clin Pract. 2010 Jan;1)87):14-4. PMID:19896746

22. Satman I, Tutuncu Y, Gedik S, Dinccag N, Karsidag K, Yilmaz T et al. Diabetes epidemic in Turkey: results of the second population based survey of diabetes and risk characteristics in Turkey (TURDEP-II). Diabetologia. 54;2011(Suppl. 1):2498.

23. Nowak MS, Smigielski J. The prevalence and causes of visual impairment and blindness among older adults in the city of Lodz, Poland. Medicine (Baltimore). 2015 Feb;5)94):e505. PMID:25654398

24. Khairallah M, Kahloun R, Bourne R, Limburg H, Flaxman SR, Jonas JB, et al. Number of people blind or visually impaired by cataract worldwide and in world regions, 1990 to 2010. Invest Ophthalmol Vis Sci. 11)56;2015):9-6762. PMID:26567788

25. Mpyet C, Solomon AW. Prevalence and causes of blindness and low vision in leprosy villages of north eastern Nigeria. Br J Ophthalmol, 9-89:417;2005. PMID:15774916

26. Watson CM, El-Asrag M, Parry DA, Morgan JE, Logan CV, Carr IM, et al. Mutation screening of retinal dystrophy patients by targeted capture from tagged pooled DNAs and next generation sequencing. PLoS One. 8)9;2014):e104281. PMID:25133751 